Revista Española de Antropología Americana ISSN: 0556-6533

https://doi.org/10.5209/reaa.64976

\title{
La plegaria armada: nuevas religiosidades para un mundo nuevo
}

\author{
Mario Humberto Ruz ${ }^{1}$
}

Recibido: 14 de diciembre de 2018 / Aceptado: 21 de mayo de 2019

Resumen. Como es sabido, la conquista hispana y sus secuelas de colonización y adoctrinamiento católico representaron un ataque demoledor contra las modalidades mesoamericanas de concebir la existencia y pasar a su través. Ante ello, los pueblos mayas recurrieron a menudo, entre otras estrategias, a la sustitución de ciertos referentes religiosos antiguos por otros de factura cristiana, que les facilitaron desplegar los mecanismos necesarios para ajustar contenidos de pensamiento y actitudes vitales, adaptándolos a la nueva realidad, bien en tiempos de guerra, bien en la cotidianeidad.

Palabras clave: resistencia y religiosidad maya; luchas armadas; épocas colonial e independiente; México; Guatemala.

\section{[en] The Armed Prayer: New Religiosities for a New World}

\begin{abstract}
As is well known, the Spanish conquest and the repercussions of colonization and Catholic indoctrination represented a demolishing attack on Mesoamerican ways of conceiving existence and passing through that existence. Faced with this reality, Mayan communities frequently resorted, among other strategies, to the substitution of certain ancient religious referents with Christian ones, which allowed them to enact the mechanisms necessary to adjust thought content and vital attitudes by adapting them to the new reality, whether in times of war or peace.
\end{abstract}

Keywords: Mayan resistance and religiosity; armed conflict; colonial and independent eras; Mexico; Guatemala.

Sumario. 1. De montañas, grutas, pirámides, guajolotes y «ángeles mal formados». 2. Estrategias compartidas, particularidades regionales. 3. Los cambiantes signos de los tiempos. 4. Los soldados de la Virgen; el «pequeño Moctezuma». 5. Al llamado de la Cruz parlante. 6. De resistencias ocultas y soterradas. 7. Referencias.

Cómo citar: Ruz, Mario Humberto. 2019. «La plegaria armada: nuevas religiosidades para un mundo nuevo». Revista Española de Antropología Americana 49 (número especial): 349-371.

\footnotetext{
${ }^{1}$ Centro de Estudios Mayas, Instituto de Investigaciones Filológicas, Universidad Nacional Autónoma de México. mhruzs@gmail.com.
} 
No creerán los hombres mayas. Será cantada dentro de ellos la palabra de Dios, el Señor del Cielo... Los viejos hombres mayas no quieren oír la palabra de Dios. Poco es lo que creen, y ni eso creen tampoco. Chilam Balam de Chumayel (1980: 278)

\section{De montañas, grutas, pirámides, guajolotes y «ángeles mal formados»}

E1 8 de marzo de 1797, fray Macedonio Sarabia, cura de Jacaltenango, situado en la frontera entre las alcaldías de Chiapa y Huehuetenango, se dirigió al secretario del Obispado de Guatemala para informarle de un descubrimiento que, si bien venía a aumentar las tareas que se le había encomendado realizar en su curato, asolado por una severa «peste», servía en su opinión para entender el origen de la epidemia: se trataba de un castigo divino por idolatría ${ }^{2}$.

Los responsables directos eran los vecinos del pequeño pueblo de La Concepción, quienes efectuaban rituales en un asentamiento prehispánico, de lo que pudo enterarse el fraile gracias a la presión que ejerció sobre un muchacho puesto a su servicio. Forzados, dos adultos lo condujeron al sitio a él y a algunos funcionarios civiles, tras intentar antes «perderlos» por montañas y barrancos.

«Y vamos encontrando, a las dos leguas largas del pueblo, de un camino fatalísimo, junto a la cabecera de un río que se llama de San $\operatorname{Marcos}^{3}$, en un lugar muy ameno, el dicho adoratorio, y era de este modo: un teatro de finísima mezcla y de muy buena lajería de cuatro varas en cuadro, y tres varas largas de alto, con dos puertas [...] de nueve gradas cada una, sus cuatro pirámides en las esquinas, y en medio una a manera de tumbilla. Abajo de dicha fábrica, una cuevecita de piedra bien canteada, con una figurita de barro dentro, braseros de copal por todas partes, y muchos candeleros».

En ese sitio, de nombre Bacú, los jacaltecos, pese a conceptuarse a sí mismos como buenos cristianos, iban a ofrecer, además del copal, velas y sangre de pavos a Culman 4 , Señor Grande, y Culmí, Señora Grande ${ }^{5}$ Interrogados por la justicia civil española declararon que acudían a la cueva los padres de un recién nacido para ofrecerlo, «pidiendo tuviesen fortuna», para lo cual quemaban copal, prendían velas y efectuaban rogativas. Pero no sólo ellos; incluso las autoridades nombradas por el Gobierno colonial iban cuatro veces al año:

«La primera en año nuevo, a dar las gracias de las varas [recibidas como símbolo de autoridad].

La segunda, a principios de invierno a rogar se diesen sus siembras.

La tercera, a fines de invierno para cogerlas buenas.

\footnotetext{
2 AHAG, «Expediente que trata de la idolatría en que han incurrido los indios del pueblo de la Concepción, del curato de Jacaltenango, y otros puntos que en él se hallarán». 1797, ff. 70-78. Mantengo la ortografía del manuscrito, si bien modifiqué en ocasiones la puntuación para facilitar la lectura. Ofrecí éstos y otros datos sobre este documento en un texto previo (Ruz 2007).

3 Hoy llamado río Azul.

4 También se registra como Cuman en el mismo documento, y el asentamiento aparece en alguna parte como Bacul.

5 Collins apunta que dicho templo marcaba el lugar de entierro del «primer patriarca de los jacaltecas, y era el santuario de éste y de su esposa, la primera matriarca...» (1989: 16). No encuentro tal aseveración en el documento del AHAG; acaso haya consultado otro documento sobre el mismo tema, lo infiera de sus nombres, o quizá obtuvo el dato de la tradición oral. Agrega la autora que aún hoy los alcaldes rezadores realizan rituales en el sitio, «considerado el lugar donde descansan los primeros padres de la estirpe jacalteca» (op. cit.: 17-18).
} 
La cuarta, al fin del año a dar las gracias [las autoridades por] que acababan [en el puesto] con felicidad.

En cada ocasión de éstas iban el primer mayor, y primer regente electo y un principal, a media noche, y mataban un chumpipe [guajolote]. Iban a quemar allí la mitad de la sangre y la otra mitad la venían a quemar a la iglesia, y después se iban a comer el chumpipe al [edificio del] cabildo».

Así pues, además de seguir velando por la fortuna y la alimentación de su pueblo, los sacros antiguos guardianes - cuyos nombres parecerían aludir a abuelo (mam) y abuela $\left(m i^{\prime}\right)^{6}$, y a su cualidad de sagrado $(k u)$ - seguían cuidando del buen desempeño de las autoridades, aunque éstas fuesen ya elegidas a la usanza hispana. El don de un animal americano servía para amalgamar, sin mayores problemas, añejos referentes del poder cívico-religioso (cuatro pirámides, un altar central), con la iglesia y casa del Cabildo, los dos edificios símbolo del nuevo orden religioso y colonial. La sangre del guajolote, tan apreciada como en tiempos pasados, se ofrendaba tanto a las deidades de siempre como a las impuestas; ésas que los mayas jacaltecos, como tantos otros pueblos mayanses, habían terminado por hacer suyas.

Se requirió la ayuda de 30 soldados venidos desde Huehuetenango para destruir el adoratorio, y plantar una cruz. Más tarde se quemaron 106 «ranchos» aledaños. Luego, siguiendo las instrucciones del arzobispo Juan Félix (quien ordenó al cura atender «a la rusticidad e ignorancia de que acaso se hallaran poseídos los delincuentes $[. .$.$] procurando siempre evitar que por miedo de las penas o penitencias se$ abandonen a vivir en las montañas o despoblados»), se realizó en la iglesia un acto penitencial,

«[...] donde, desnudos de medio cuerpo arriba los hombres, y las mujeres con su pelo tendido, y lo mismo los párvulos de ambos sexos [...] hicieron juramento de no volver a incurrir en el pecado de idolatría que detestaron. Y manifestaron estar arrepentidos. Y les absolví [...], dándoles a unos y otros suavemente con una vara, y rociando la iglesia con agua bendita [allí donde se había quemado la sangre del pavo] les impuse por penitencia que saliesen en procesión con cruces por las calles del pueblo».

A los penitentes idólatras se les obligó a trasladar las piedras del adoratorio para consolidar el templo cristiano y reparar las cuatro capillas del atrio (es de suponer las llamadas capillas posas), que estaban arruinadas. Con ello, se ubicaron en un mismo lugar basamentos y pilares de creencias y símbolos de viejo y nuevo cuño.

Ese mismo año el cura de Totonicapán alertó acerca de la «heredada adicción a los abusos y supersticiones» que mostraban sus feligreses, quienes alentaban la continuidad de esas creencias y prácticas, depositando en la cueva llamada Pacahá los cordones umbilicales «de criaturas recién nacidas, que, como se les caen [los cordones], los llevan, con la supersticiosa creencia de que con esto, cobraran los indiezuelos amor a aquel monte», pues en ese «adoratorio» se reunían los vecinos mames de Santa Catarina Ixtahuacán, poseedores de «grandes majadas de ganado menor», y pedían por «la fecundidad y felicidad de sus crianzas». Lo estilaban en particular el día llamado Nima Kíj, cuando ofrendaban incienso y velas, y hacían otras «imprecaciones ridículas» a las imágenes esculpidas en las paredes, «figurones de ángeles mal formados o con alusión de diablos» ${ }^{7}$.

\footnotetext{
6 Todavía hoy se emplean en la lengua popti' o jacalteca como clasificadores de respeto para señor: mam, y señora: $m i$ ' (Delgado et al. 2007: 83).

7 AHAG, procesos contra indios y mestizos por hechicería e idolatría. $2^{\circ}$ legajo, exp. VIII, San Miguel Totonicapan,
} 
No habían pasado ni cuatro años cuando fue descubierto un sitio similar en Santa Eulalia, también en las montañas de los Cuchumatanes. Se trataba de una cueva natural ubicada justo bajo la capilla del calvario, a la que se llegaba por una entrada secreta al lado de un «precipicio», donde se encontraron altares naturales y restos de numerosas ofrendas a los considerados «primeros padres». Se selló la entrada y se azotó a las autoridades para disuadir al pueblo de seguir practicando ritos semejantes, pero aún hoy sigue siendo espacio sagrado y celosamente vigilado como morada de los progenitores originarios; se visita en etapas cruciales del ciclo agrícola a fin de asegurar la llegada de las lluvias o prevenir vientos y heladas (Collins 1989: 19ss).

\section{Estrategias compartidas, particularidades regionales}

Popti's de Jacaltenango, kaqchikeles de Totonicapán, mames de Ixtahuacán y kanjobales de Santa Eulalia seguían pues, a escasos años de concluir el dominio español en América y a casi tres siglos de iniciado su adoctrinamiento cristiano, reverenciando a antiguas deidades cuyas moradas ubicaban en los montes, las grutas y en antiguos asentamientos precolombinos. No eran los únicos; los documentos coloniales dan fe de que el hecho era común en diversas etnias y numerosos pueblos, en muchos de los cuales, según se advierte en la literatura etnográfica, persisten hasta hoy creencias y rituales en los que es posible advertir componentes de origen prehispánico.

Resulta tentador pensar que tales actitudes se manifestaran en particular en periodos de «crisis» ante las cuales los pueblos mayas buscasen ampararse en la seguridad del sistema de creencias y prácticas en boga antes de la conquista y colonización hispana. Tentador, pero inexacto. Bien mirado, el devenir histórico de los pueblos mayas supo de periodos de crisis desde antes de que Occidente irrumpiera en tierras americanas y, lo que es más significativo, en las respuestas que tenemos documentadas a partir de la conquista surge claro que, con mayor o menor celeridad, los mayas fueron capaces de desplegar los mecanismos necesarios para ajustar contenidos de pensamiento y actitudes vitales, adaptándolos a la nueva realidad.

Uno de tales mecanismos, particularmente socorrido, fue justo la sustitución de determinados referentes religiosos mayas por otros de factura cristiana. Nada extraño; tal estrategia ya se había empleado antes, en tiempos remotos, cuando influencias venidas de los altiplanos centrales del actual México introdujeron al panteón maya deidades y prácticas de nuevo cuño, como el culto a Quetzalcóatl, rebautizado en maya Kukulcán; idéntico significado, misma serpiente emplumada, desplegando sus alas en cielos tropicales, en los densos bosques de coníferas o en las altas montañas de los Cuchumatanes.

Ciertamente en el caso del cristianismo no fue posible levantar templos gemelos sobre las pirámides; el nuevo dios entronizado no toleraba rivales, pero la pléyade de santos y vírgenes acompañantes facilitó las amalgamas, en particular con las deidades propias de los contingentes laborales (agricultores, cazadores, pescadores, comerciantes, etc.) o las de los conglomerados familiares.

Cabe asimismo recordar que, pese a la imagen pasiva que la vieja historiografía nos trasmitió acerca de la experiencia colonial, nuevos estudios basados más en documentos que en crónicas eclesiásticas y reportes oficiales muestran que la 
interrelación de los pueblos mayas con los hispanos -aunque en tiempos y ritmos diversos- estuvo tachonada de violentos y dolorosos movimientos sociales de protesta armada (Figura 1) frente a la perturbación de un modo de ser; ataque frontal contra una manera peculiar de concebir la existencia y pasar a su través.

Pero, habiendo compartido una obertura de sangre y violencia, los escenarios sociales se diversificaron a lo largo y ancho de la puesta en escena de la obra colonial. Así, es posible constatar desde la colaboración hasta el enfrentamiento, pasando por las fracturas étnicas, los reacomodos de los miembros de ciertas elites, el canalizar de la frustración y la rabia de los sacerdotes, o el estupor casi paralizante que experimentaron muchos miembros del común al verse cercenados de sus dioses, sus creencias y sus dirigentes.

Lo anterior, empero, no significa, por supuesto, que al desaparecer durante la conquista (militar e ideológica) los jefes militares o los guardianes del conocimiento especializado, desapareciese la cultura maya. Asumir tal supuesto equivaldría a reducir a ésta a las expresiones de su élite y minimizar la vitalidad del pueblo, que, amén de poseer otras facetas de cultura y conocimientos, se reveló capaz de concebir diversos y variados tipos de respuesta.

La respuesta, en efecto, no fue uniforme. Junto a aquellos que comprendieron que la pesadilla había llegado para instalarse durante largo tiempo, hubo quienes se refugiaron en actitudes fatalistas o en el ensueño de una antigua edad dorada (a menudo artificialmente re-creada, como aquella que hablaba de un pasado donde no había ni tributos ni enfermedades) y también los que optaron por ir construyendo, desde el presente desmoronado, un futuro de reivindicaciones. Peculiaridades regionales, de etnias, comunidades, estratos sociales e incluso individuos, que si bien invalidan las homogeneizaciones burdas, no por ello cancelan la posibilidad del análisis comparativo en materia de resistencia, tanto en lo que toca a los tiempos, como a los actores y los caminos de la resistencia. En esta ocasión privilegiaré lo relativo al campo de lo religioso, pero advierto que no fue éste el único y en ocasiones ni siquiera el más importante ${ }^{8}$.

Aspecto también a tomar en cuenta es que, dadas las variadas formas de dominio y sumisión, y la diversidad de épocas y espacios, no es de extrañar que los pueblos mayas esgrimieran ante ellas actitudes diferentes - conscientes algunas, ancladas otras en el inconsciente-, las cuales podían mostrarse incluso cambiantes a lo largo del devenir colonial: el adversario de hoy podía ser el aliado de mañana; la que en un momento se avalaba como estrategia eficaz podría exhibir su obsolescencia en el siguiente; aquello que en cierta época se percibía como ajeno podía haber pasado ya, en la que le sucedía, a formar parte de lo propio.

Así por ejemplo, la virgen María, que en el Cozumel del 1520 se enfrentó a la diosa maya Ixchel, pudo mostrarse dos siglos después como adalid de la lucha de los tseltales y tsotsiles que se rebelaron en Chiapas en 1712 contra el dominio español. Asimismo, con el paso del tiempo los especialistas religiosos mayas optaron por iniciar los antiguos rituales con una invocación a la Santísima Trinidad o a determinados santos, a fin de asegurarse la benevolencia de una mayor cantidad de entidades tenidas por taumatúrgicas o protectoras, mientras que grupos como los k'ichés de Suchitepéquez decidieron amarrar los huesos de sus antepasados con la cruz cris-

\footnotetext{
He tratado de otros aspectos de la resistencia, bien armada, bien cotidiana en textos previos (entre los más antiguos, Ruz 1992 y 1997).
} 


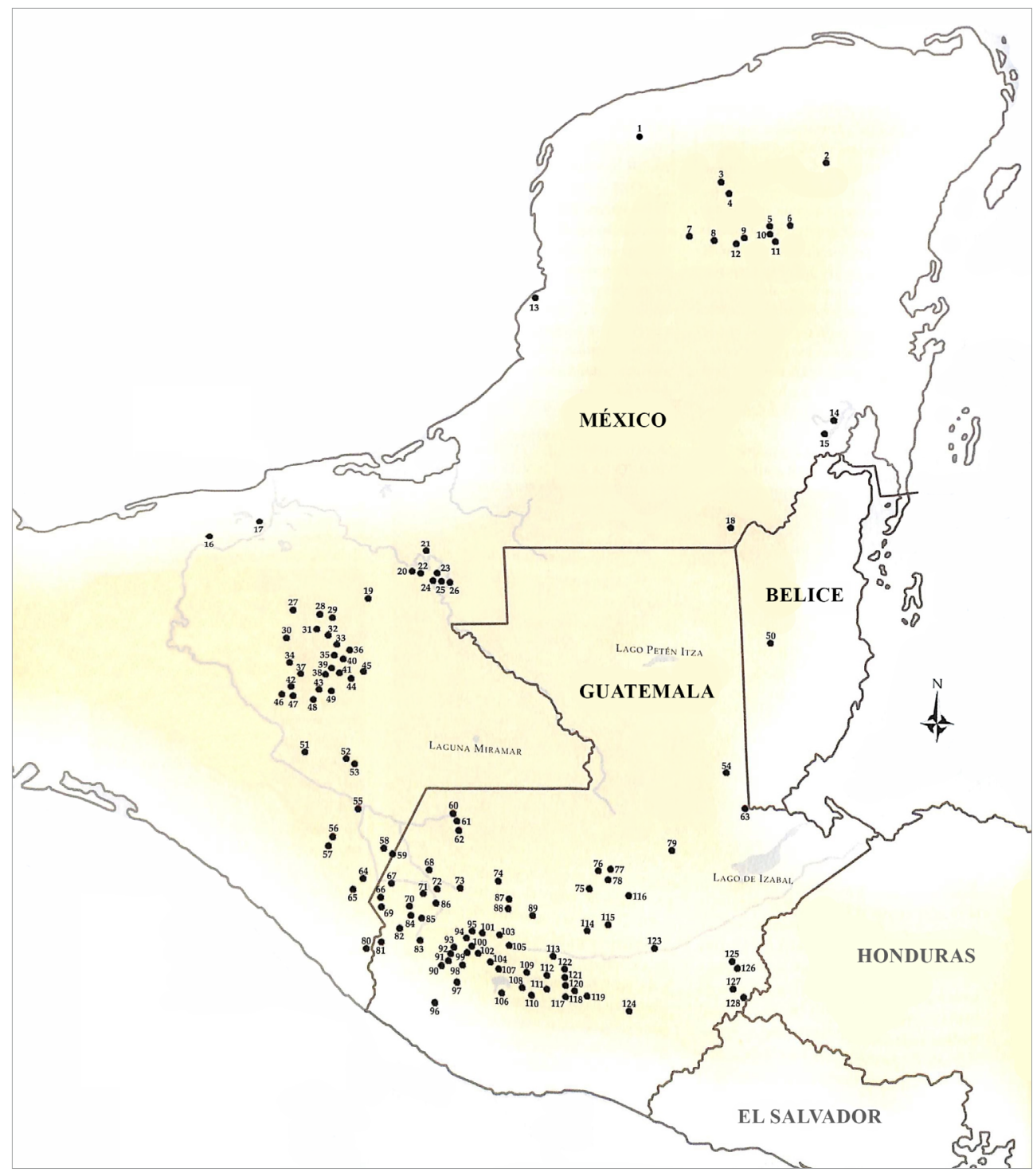

Figura 1. «Poblados participantes en levantamientos documentados en el área maya durante la época colonial». (C) Mapa original, Ruz 1992; ilustración digital Raíces (en Ruz 2011: 5051). 1: Mérida (1761). 2: Valladolid (1546, 1565). 3: Sotuta (1538, 1597). 4: Cisteil (1761). 5: Tiholop (1761). 6: Ekpez (1761). 7: Tekax (1610). 8: Tixmhuac (Tixmeual) (1761). 9: Tixhualahtún (1761). 10: Tinum (1761). 11: Ichmul (1761). 12: Peto (1783). 13: Campeche (1562, ca. 1582). 14: Chichanhá (1639). 15: Bacalar (1546, 1636, 1683). 16: Cunduacán (1727). 17: Tamulté de Las Sabanas (1701). 18: Zaclún (1624). 19: Palenque (1712, 1727). 20: Tamulté Popane (1668-1671). 21: Balancán (1668-1671). 22: Istapa (1668-1671). 23: Canizán (1668-1671). 24: Usumacinta (1668-1671). 25: Petenecte (1668-1671). 26: Tenosique (1668-1671). 27: Moyos (1712). 28: Tila (1712, 1727). 29: Tumbalá (1712, 1727). 30: Huitiupán (1712, 1727). 31: Petalcingo (1712, 1727). 32: Yajalón (1712). 33: Chilón (1712). 34: Chalchihuitán (1712). 35: Sitalá (1712). 36: Bachajón (1727). 37: Chenalhó (1712). 38: Tenango (1712). 39: Sibacá (1712). 40: Guaquitepec (1712, 1727). 41: Cancuc (1712, 1727). 42: Chamula (1712). 43: Tenejapa (1712). 44: Teultepec (1712). 45: Ocosingo (1712, 1727). 46: Zinacantán (1712). 47: Ciudad Real (hoy San Cristóbal de Las Casas) (1730). 48: Huixtán (1712). 49: Oxchuc (1712). 50: Tipú (1540, ca. 1638). 51: San Bartolomé de Los Llanos (hoy Venustiano Carranza) (1701, 1778). 52: Soyatitán (1701). 53: Socoltenango (1701). 54: San Miguel Manché (1630, 1678). 55: Escuintenango (1701). 56: Chicomuselo (1701). 
tiana que reinaba en la iglesia. La empresa era perdurar, y como para ello no había reglas escritas -ni en la antigua ni en la nueva tradición- éstas tendrían que estarse inventando y recreando una y otra vez.

Exceptuando algunos movimientos registrados en los momentos iniciales la documentación no parece apuntar a que los mayas lucharan por un retorno a las condiciones previas a la invasión europea (condiciones, recordemos, que tampoco eran particularmente democráticas), sino por mantener dentro de límites «tolerables» las mojoneras de la explotación y el sometimiento, incluyendo el religioso. Y lo que se entendía por «tolerable» variaba dependiendo de la época y el grupo.

Como ejemplos de las actitudes iniciales antes señaladas, por lo común de rechazo a la nueva religión, permítaseme evocar algunas de una misma área a la que poco se alude en los estudios mayas: la Alcaldía Mayor de Tabasco. Allí, la resistencia a la evangelización y el apego a los antiguos dioses se alegaron incluso como cargos para sentenciar en 1541 al señor de Amatitán, dos caciques de Chichicapa y otro indígena de Oceloteupa, a ser arrojados vivos a mastines hambrientos (Ruz et al. 2000), mientras que en 1550, cuando fray Diego de Béjar derribó a los dioses que ornaban sus altares, algunos mactunes de Itzamkanac, guiados por sus señores, se internaron en la selva llevando consigo a las deidades de sus antepasados y restauraron su culto en los densos bosques tropicales vecinos (Scholes y Roys 1968: Apéndice A).

Sin duda alguien podría apuntar que las muestras de actitudes de colaboración por parte de los señores étnicos pueden multiplicarse en forma significativa, y hasta más abundante. Cierto, pero conviene recordar también que el que participasen activamente en distintas esferas de la religiosidad católica, no significaba, en modo alguno, que los señores hubiesen olvidado por completo creencias y prácticas de su antigua religión, o renunciado a ellas.

Baste recordar el ejemplo paradigmático de Yucatán, donde caciques y principales, no presentaron en un principio mayor oposición ante el nuevo sistema, pues les permitía seguir gozando al menos de una porción de su antiguo poder (Bracamonte

(Figura 1, continuación) 57: Yayahuita (1701). 58: Comalapa (1701). 59: Santo Domingo Xenacoj (Samayac) (1821). 60: San Mateo Ixtatán (1697, 1803). 61: Santa Eulalia (1653). 62: San Pedro (Soloma) (1744, 1803). 63: San Lucas Salac (1630, 1678, 1689). 64: Mazapa (1701). 65: Motozintla (1701). 66: Magdalena Tactitán (1701). 67: Cuilco (1701). 68: Santiago Chimaltenango (1701). 69: Tacaná (1701). 70: Concepción Tutuapa (1701). 71: San Miguel Ixtahuacán (1701). 72: Santa Bárbara Totonicapán (1790). 73: Chiantla (1803). 74: Nebaj (1775, 1793, 1798). 75: Cobán (1735, 1802, 1803). 76: San Pedro Carchá (1735, 1803). 77: San Juan Chamelco (1686, 1735, 1751). 78: Verapaz (1574). 79: Santa María Cahabón (1808). 80: Santa Ana Malacatán (1814-1815). 81: Tuxtla Chico (1701). 82: Tajumulco (1701). 83: San Pedro Sacatepéquez (Quetzaltenango) (1701, 1805). 84: Santiago Tejutla (1701). 85: Santa Cruz Comitán (1701). 86: San Bartolomé Sipacapa (1701). 87: Sacapulas (1820). 88: Rancho de Teja (1825). 89: San Andrés Sajcabajá (1819-1820). 90: San Martín Sacatepéquez (1815).

91: Chiquirichapa (1701, 1815). 92: San Andrés Xecul (1815). 93: San Juan Ostuncalco (1701, 1711, 1815). 94: San Francisco el Alto (1696, 1821). 95: Santiago Momostenango (1785, 1812). 96: Retalhuleu (1701, 1782). 97: Quetzaltenango (1569, 1710,1785, 1807, 1815). 98: Santa Catarina Zunil (1811). 99: Salcajá (1802). 100: San Miguel Totonicapán $(1679,1736,1814,1818,1820)$. 101: Santa María Chiquimula $(1802,1804,1818,1819$, 1820). 102: San Cristóbal Totonicapán (s/f, 1820). 103: Santa Lucia Utatlán (1760, 1771). 104: Santa Catarina Ixtahuacán (1743, 1814). 105: Chichicastenango (1813). 106: Santiago Atitlán (1800). 107: San Miguel Sololá (1576, 1811). 108: Patzún (1796, 1801). 109: San Francisco Tecpán (1759). 110: Patzicia (1811, 1821). 111: Santa Ana Chimaltenango (1813). 112: San Juan Comalapa (1744, 1755, 1774, 1812). 113: San Martín Jilotepeque (1531, 1791). 114: San Pablo Rabinal (1580, 1678, 1680, 1686, 1751). 115: Salamá (1821). 116: Tucurub (1686) 117: San Lucas Sacatepéquez (1526). 118: Sumpango (1799). 119: Ciudad de Guatemala (1766). 120: Santiago Sacatepéquez (1811). 121: San Pedro Sacatepéquez (1526). 122: San Juan Sacatepéquez (1526). 123: San Agustín Acasaguastlán (1776). 124: Santiago Mataquescuintla (1774, 1824). 125: Jocotán (1749). 126: Camotán (1749). 127: Quezaltepeque (1749). 128: Esquipulas (1749). 


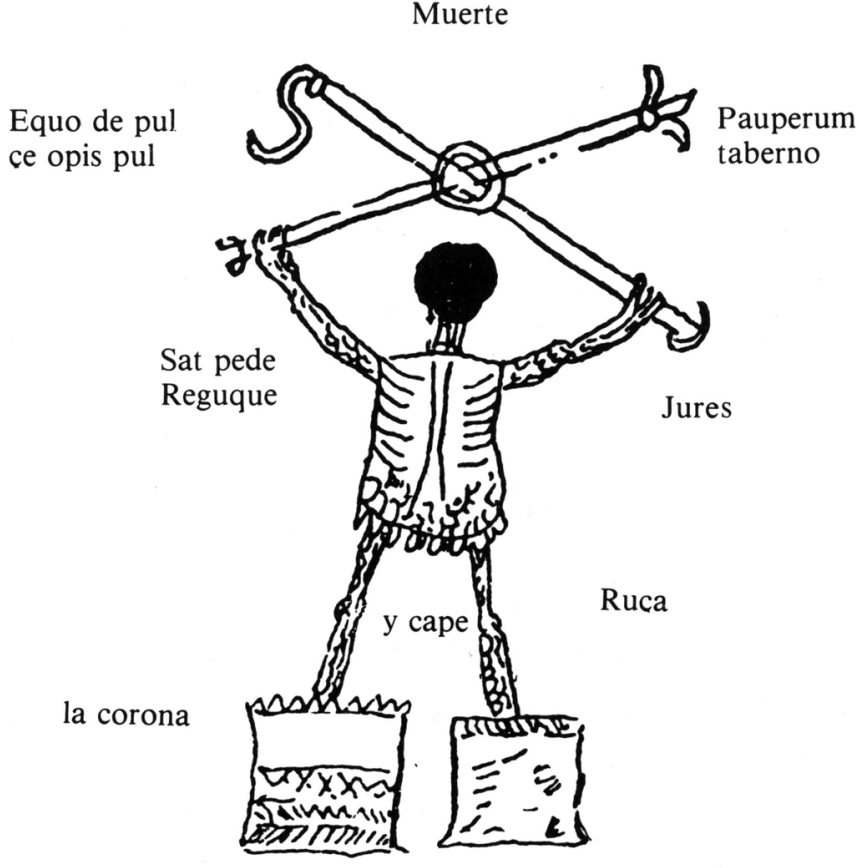

Con igual pie y Cruca
Figura 2. «La muerte reina sobre todo». Chilam Balam de Chumayel (1980: 251).

y Solís 1996), pero cuando en 1562 los franciscanos se percataron del papel que jugaban los señores en el mantenimiento de la antigua religión (Chuchiak 2005), se hicieron patentes los riesgos que se desprendían de la continuidad de su dominio y prestigio, por lo que los frailes aceleraron el proceso transformador y propugnaron por la creación de cabildos y el nombramiento anual de los oficiales de república, para transitar de puestos hereditarios a otros «por encargo» (Quezada 1993). Eso no significó, empero, que los antiguos señores y las nuevas autoridades abandonasen los rituales de sus antepasados; y no necesariamente lo hicieron siempre por fidelidad religiosa: el mantenimiento del poder y el prestigio y la obtención de prebendas económicas no fueron ajenos al asunto (Ruz 2018).

Sea como fuere, pensar que los mayas apostaron por el anquilosamiento es adobar posturas carentes de fundamento histórico; la nostalgia por una edad de oro igualitaria (que nunca existió) aparece tan sólo en algunos testimonios coloniales (vg. los Chilam Balam), surgidos de la pluma de los dirigentes que veían con apremio la pérdida de sus antiguos cotos de poder, y se consolidó gracias a la visión romántica de ciertos investigadores que poco tiempo emplearon en la consulta de los materiales de archivo. De tales documentos se desprende, más que un afán pertinaz por retornar al pasado, la apuesta por hacer más llevadero el presente.

Un presente que no pocos mayas concibieron como de sufrimiento y muerte, como se desprendía, entre otras muchas cosas, de la insistencia franciscana en el sacrificio de Cristo y su discurso escatológico. No en balde apuntaron los escribas del Chilam Balam de Chumayel: «Ceñudo es el aspecto de la cara de su dios. Todo lo que enseña, todo lo que habla es: '¡Vais a morir!'» (1980: 273), agregando un dibujo (Figura 2) que titularon: «La muerte reina sobre todo». 


\section{Los cambiantes signos de los tiempos}

El abanico de significantes y significados a preservar, rechazar o reinterpretar varió, pues, en consonancia con el signo mismo de los tiempos. En un inicio hubo quienes apostaron por extirpar de cuajo todo lo aportado por los conquistadores. Muestra clara de ello fue el levantamiento protagonizado por los Cupules en noviembre de 1546 en Valladolid, Yucatán, en el que participaron mayas de las provincias de Sotuta, Ah Kin Chel, Cochuah y Calotmul. En él, en un denodado esfuerzo por erradicar de una vez y para siempre toda traza de los detestados invasores, se intentó acabar no sólo con ellos, sino que se mató a decenas de indios (considerados «traidores») que habían aceptado servirles, se ultimó a gatos y perros traídos de Occidente y hasta se arrancaron los «árboles de Castilla» (Relaciones Histórico-geográficas de la Gobernación de Yucatán, Relación de Mérida 1983, 1: 67).

Dos décadas más tarde los k'ichés de Quetzaltenango, amotinados, apedrearon al cura, se burlaron de referentes cristianos como el Santísimo Sacramento, apalearon a los funcionarios civiles y asesinaron a residentes españoles. Bien lo expresó uno de los rebeldes: «que no se le daba nada del rey ni de la justicia; que no querían que hubiesen ni entrasen españoles en este pueblo» (Zamora 1986: 204-208).

Para el siglo XVII, en revueltas como la de Tekax, Yucatán, en 1610, vemos una franca conjunción de referentes. Allí los instigadores, a decir de los hispanos, se nombraron papa y obispo, y al tiempo que promovían la ingestión de balché, el licor ritual, en copones y cálices, administraban bautismos y comuniones, confesaban, ordenaban sacerdotes y organizaban procesiones para las imágenes de sus antiguos dioses, pero a la usanza católica. Al gobernador Pedro Xiu, aliado de los españoles y representante por tanto de la vieja y nueva opresión, se le condenó con un pregón público (como hacían los hispanos) y cuando los frailes franciscanos pretendieron protegerlo, se les tildó de «sediciosos» (Porro 1977: 65-67); exactamente el mismo calificativo que empleaban los europeos para calificar a quienes turbaban el orden cotidiano.

Al tiempo que don Pedro y algunos otros nobles se aliaban con las causas hispanas, no faltaron principales que apoyasen el mantenimiento de antiguas creencias y prácticas. Así, a lo largo de la Colonia menudearon acusaciones por actividades rituales con tintes considerados idolátricos, en los que se vieron involucradas distintas autoridades mayas. Ocurrió en 1694, cuando se denunció por ello a principales y hasta a algún batab de los pueblos de Kikil, Suquilá, Panabá y Chuchuen. Misma acusación que se había hecho en 1574 a un cacique de Campeche, en 1590 a los caciques de Cozumel, en 1595 al cacique de Chunhuhub, al año siguiente al cacique de Dzismopo, en 1598 a un principal de Peto, en 1606 a tres principales de Yobaín, en 1610 al cacique de Maxcanú, en 1640 al cacique y otros principales de Tibac'. Los acusados sufrieron azotes, a varios se les condenó a no poder ocupar jamás otro cargo, y a algunos a trabajos forzados (Chuchiak 2004: 150ss).

En otra región del extenso mundo maya, fray Andrés de Las Navas, obispo de Guatemala, se dirigió en 1687 al presidente de la Audiencia, quejándose del escaso auxilio que prestaban él y otras autoridades civiles a las religiosas, estorbando inclu-

\footnotetext{
9 Chuchiak, en un detallado texto sobre el uso ritual del balché durante la Colonia (2004), ofrece datos y cuadros que cubren desde 1560 hasta 1813; sólo enlisto aquellos donde menciona explícitamente a caciques, principales y otras autoridades.
} 
so su labor al no permitir se castigase físicamente a los indios ${ }^{10}$. Para sustentar sus reclamos, adjuntó una serie de «certificaciones» de los párrocos, donde se detallan diferentes actitudes y prácticas de los feligreses mayas, no siempre muy ortodoxas. Entre los variados testimonios me limito a señalar, como ejemplos, que en el pueblo de Cahabón se denunció el mantenimiento de danzas antiguas (del ciclo del Tum), pese a estar prohibidas por contener «resabios» de las religiones antiguas, mientras que en San Juan Comalapa se acusó a varios indios e indias de ampararse en calendarios antiguos para realizar ceremonias en los montes, en las milpas y en las casas, vinculadas con embarazos, partos, enfermedades y actividades agrícolas, «[...] dando a entender a los demás indios e indias [que] son sahorines ${ }^{11} \mathrm{y}$ adivinan los días y tiempos más a propósito para sembrar o coger [cosechar] [...] y que a éstos llaman cholol qih, cuyo término entre los demás indios de este pueblo es muy secreto y quiere decir en castilla 'contadores de días' y sahorines»».

\section{Los soldados de la Virgen; el «pequeño Moctezuma»}

Lo que vino después fue incluso más radical que el «usar» de supersticiones e idolatrías. Hartos de ser explotados, mayas hubo que pretendieran invertir el orden, amparándose nada menos que en los referentes religiosos que esgrimían los españoles y sus descendientes, los llamados «criollos». Dos ejemplos arquetípicos de esto son la gran revuelta iniciada en noviembre de 1712 en Chiapas por tseltales, tsotsiles y ch'oles, y la que encabezó Jacinto Canek en Yucatán en 1765, también en un mes de noviembre.

La primera, que por su trascendencia, amplitud y la naturaleza de sus demandas, ha sido considerada la rebelión más importante registrada bajo el dominio español en todo el mundo maya ${ }^{12}$, ocurrió durante un periodo de hambruna provocada por varias plagas de langosta (lo que aprovecharon diversos funcionarios, incluyendo al alcalde mayor y al obispo, para medrar con la venta de granos), acompañado de un serio debilitamiento del poder regional, debido en parte a los continuos enfrentamientos entre civiles y religiosos, y la aparición de cultos nativistas en el área.

El movimiento reivindicó un principio religioso: la Virgen María se habría aparecido a una joven tseltal, María de la Candelaria, anunciándole que venía a liberar a los naturales del yugo hispano, lo que dio origen a una proclama donde se asentaba: «Ya no hay Dios, ni rey».

Puesto que se amparaba en una demanda de la propia madre de Cristo, no es de extrañar que quienes se afiliaran al movimiento se autonombraran «soldados de la Virgen», y que a los adversarios se les identificara como «enemigos» de Dios, y a su principal asentamiento, Ciudad Real (hoy San Cristóbal de Las Casas) como la residencia de los «judíos», de allí que se le rebautizara como «Jerusalén». El centro del movimiento, el pequeño poblado serrano de Cancuc, pasó entonces a llamarse «Ciudad Real» y fue declarada «capital de la Nueva España de los indios». Otro

\footnotetext{
${ }^{10}$ AGCA, A1 21, L 2, exp. 23. Fray Andrés de Las Navas, obispo de Guatemala, al presidente de la Audiencia, Enrique Enríquez, 1687.

${ }^{11}$ Zahorí: persona capaz de descubrir lo oculto. Del árabe zuharí, geomántico (Moliner 1988, II: 1570, entrada «zahorí»).

12 Apunta Severo Martínez, estudioso de este tipo de movimientos, que se trató de «el único que tuvo las características de una verdadera sublevación de indios en el período colonial centroamericano» (1982: 6).
} 
pueblo rebelde, Huitiupán, fue distinguido como «Guatemala», ya que se pretendía erigir en él una «Audiencia», y convertirlo en la sede de un Estado teocrático indígena independiente.

El nuevo Gobierno nombró «capitanes generales» al tiempo que se estableció una jerarquía eclesiástica propia, con lo que el nuevo culto adquirió visos de Iglesia autónoma -encabezada por los denominados «mayordomos de la Virgen»-que respetaba en lo esencial las formas y los símbolos de la religión católica (atavíos, misas, sacramentos, etcétera).

La violencia se propagó por toda el área, afectando a los indígenas que no se alineaban con los rebeldes, a aquellos que se habían distinguido por su anterior fidelidad a los españoles y hasta a quienes se consideró amenazaban debilitar la rebelión. Contra todos ellos funcionaron horcas y picotas. Algunos comerciantes y finqueros españoles fueron masacrados, mientras que a las mujeres hispanas capturadas se les obligó a casarse con indios o a servirles como sus criadas o mancebas, en una franca inversión del oprobioso orden existente, y en busca de un nuevo orden social, al amparo de la virgen María.

Los enfrentamientos fueron sanguinarios, pues los indios suplían su inferioridad en armamentos con arrojo y denuedo, a los que no fue ajena la promesa de que quienes murieran en combate resucitarían a los tres días. Mediando la Virgen, hasta la muerte podía ser subvertida.

Sólo gracias a la conjunción de milicias reunidas por los españoles en Chiapas, Guatemala y Tabasco, se logró sofocar el movimiento. Al gran número de muertos en los campos de batalla se sumaron cientos de ajusticiados; entre ellos casi todos los cabecillas civiles y los mayordomos de la Virgen. Cancuc fue arrasado, sembrado de sal y luego reubicado ${ }^{13}$. Una serie de plagas y epidemias que se abatieron sobre la provincia silenciaron completamente el brote de rebeldía hacia enero de 1713, al caer las poblaciones ch'oles, últimos reductos rebeldes.

No había pasado ni medio siglo cuando el mundo maya supo de un nuevo intento de liberación, esta vez en la Península de Yucatán, teniendo como centro al minúsculo pueblo de Cisteil, y como dirigente a Joseph Jacinto Uc de los Santos ${ }^{14}$.

Se trataba a todas luces de un líder distinto. Nacido en el barrio de laboríos de Campechuelo, del puerto de Campeche, hacia 1731, había sido educado por los franciscanos y conocía la historia de Yucatán. En sus planteamientos se aprecian la aguda percepción que tenía de los problemas que aquejaban a los indios peninsulares y su comprensión del mundo español.

El estar situado a caballo entre ambos universos permitió a Jacinto Uc unir inteligentemente las dos tradiciones. Así, tras un viaje a la región del Petén agregó a su nombre el de Canek, apelativo del linaje de los gobernantes itzáes, que tendían sus raíces hasta Chichén Itzá, mientras que en sus escritos se preocupó por declarar que junto al pueblo rebelde estaba el dios cristiano, a la vez que se hacía rodear de sacerdotes indígenas y apoyaba sus pronósticos de victoria en las profecías de los libros de Chilam Balam. La elección de Cisteil como núcleo para la revuelta tampoco parece fruto del azar: el pueblo se encontraba en la encrucijada de una región que había dado continuas muestras de resistencia a la colonización hispana;

\footnotetext{
${ }^{13}$ No pocos de los sublevados fueron reacomodados en lugares distantes.

${ }^{14}$ Sobre este levantamiento véase Patch (2003), Bracamonte (2004). Los documentos de la época constan en Bracamonte y Solís (2005).
} 
próxima a las antiguas provincias mayas de Cupules, Sotuta y Cochuah, justamente aquellas que participaron con mayor ahínco en el levantamiento de 1546 que mencioné antes.

La revuelta fue planeada para estallar en 1762 y desde octubre de 1760 empezaron a circular cartas por la Península para sumarse a ella, pero la filtración de información precipitó las cosas, por lo que el 20 de noviembre de 1761 Canek se vio urgido a arengar a su gente para que secundara el levantamiento, declarando: "Yo he caminado por toda la provincia y registrado todos sus pueblos, $\mathrm{y}$, considerando con atención qué utilidad o beneficio nos trae la sujeción a España..., no hallo otra que una penosa e inviolable servidumbre».

Ejemplificó lo dicho con los abusos de eclesiásticos, funcionarios y civiles que no se saciaban ni con la labor india ni con la sangre que los azotes arrancaban de sus cuerpos. Luego, a decir de algunos testigos, ejecutó actos de magia y prometió a aquellos que le siguieran que contarían con el apoyo de los ingleses, en tanto que quienes murieran en la batalla resucitarían al tercer día o, al menos, encontrarían abiertas las puertas del Paraíso ${ }^{15}$.

En medio del entusiasmo Canek fue investido como rey, según sus detractores, con la corona, el manto y el cetro de una imagen de la virgen, y con el título de José Jacinto Uc de los Santos Canek Chichán Moctezuma («pequeño Moctezuma»); título no totalmente maya, pero sí particularmente significativo. Luego, según ciertos testigos, abolió los tributos, ordenó distribuir entre sus seguidores las mantas y animales que se habían acumulado para entregar a los españoles, y realizó nombramientos de gobernadores, capitanes generales y tenientes, a más de certificar a los caciques y principales que se ofrecieron a apoyarle, incluso desde poblados de Campeche. Todo ello contribuyó a que se le identificase como reencarnación de Kukulcán-Quetzalcóatl, llegado de nueva cuenta por el Oriente para liberar a los mayas.

Él negaría más tarde haber hecho tales cosas, aunque aceptó haber ordenado matar a todos los cerdos del pueblo «porque los cochinos eran alma de españoles»y haber asentado que la virgen era esposa de san José «y que también era su mujer, por ser rey de la tierra». Otros interrogados afirmarían que si bien incitó a exterminar a los hispanos, aseguró que a algunas de las españolas «principales» se les perdonaría la vida para desposarlas con sacerdotes y capitanes mayas. Se anunciaba ya que el famoso pueblo de Maní sería la capital de los mayas independientes...

La primera batalla favoreció a los rebeldes, pero los españoles se apresuraron a juntar 3.500 hombres, que atacaron el poblado con mosquetes, lanzas, sables, fuerzas de caballería y hasta un cañón, mientras que los mayas, aun cuando equivalentes en número, estaban provistos apenas con piedras, palos de telar tallados en forma de sables y cerca de 30 escopetas de caza, dotadas a lo más de cuatro tiros. Confiados en los poderes mágicos de su líder, hubo quienes fabricaran «pólvora» con cáscaras de naranja. ¿No se había asegurado acaso que las armas de los españoles dispararían agua en lugar de balas?

Tras dos horas de combate cayó Cisteil, que fue arrasado y quemado. Los soldados muertos alcanzaron los 40; los rebeldes, más de 500, incluyendo ocho sacerdotes que, junto con las imágenes de sus dioses, perecieron en las llamas. Canek y cerca de

\footnotetext{
${ }^{15}$ En su juicio Canek mismo apuntó haber depositado agua sobrante de cuatro calabazas en dulce en un cáliz y que «con aquella había de ungir a los indios que muriesen, para que resucitasen» (Bracamonte y Solís 2005: 146).
} 


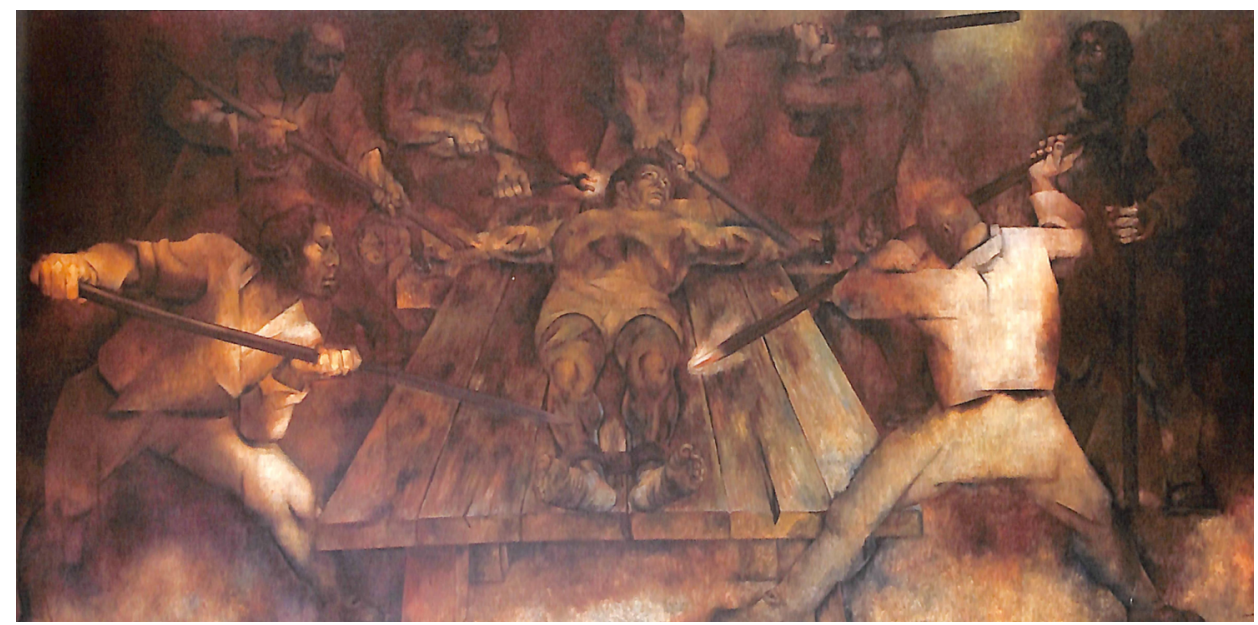

Figura 3. «El suplicio de Canek», Fernando Castro Pacheco. (C) Mural en el Palacio de Gobierno, Mérida, Yucatán.

300 hombres lograron escapar y continuaron dando batalla en los bosques vecinos, pero terminaron por ser hechos prisioneros.

Mérida, que celebró «la victoria de las armas católicas» con las campanas al vuelo y un Te Deum, se engalanó como para una fiesta para ver desfilar a más de 400 prisioneros. A ocho de los considerados caudillos se les ejecutó de inmediato en la horca, y sus manos y cabezas fueron enviadas «como ejemplo» a sus pueblos de origen (donde ya se había ajusticiado a otros, sin mediar juicio alguno), y a lo largo de dos días se entretuvieron las justicias en castigar «porción considerable de indios, de mañana y tarde», con azotes y corte de orejas, a más de trabajos forzados.

A los 135 a quienes se consideró más involucrados se les condenó también a la horca, pero en vista de las cercanas fiestas navideñas se difirió su ejecución. Tiempo después sus sentencias serían conmutadas por 100 o 200 azotes, ocho años de trabajos forzados en los astilleros de La Habana o seis en obras públicas, dependiendo de la magnitud de su participación. Los caciques campechanos de Lerma y San Román, que habían mostrado cierta «simpatía» por el movimiento, terminaron sus días en las mazmorras de San Juan de Ulúa.

El castigo para el líder debía ser ejemplar: se le hizo desfilar por Mérida vestido de manera humillante, con una corona de piel de venado como mofa a su pretendida realeza. Tras un veloz «juicio» se le condenó a ser «roto vivo», «quebrando los brazos y piernas a golpes», y a que su carne fuese desgarrada con tenazas (Figura 3). Una vez muerto «naturalmente», se le expondría tres horas en «dicho cadalso para que todos lo vean [y luego] se quemará su cuerpo y sus cenizas se darán al viento».

El bestial suplicio se realizó la mañana del 14 de diciembre, frente a 69 sobrevivientes de la batalla. Brutalmente destrozado el cuerpo, de 30 años, se mantuvo expuesto hasta las dos de la tarde. Luego, las cenizas y las ansias libertarias de Canek se esparcieron en el aire.

Se esparcieron... pero no desaparecieron. Alentaron el espíritu de lucha de los mayas cuatro katunes después, en una despiadada Guerra de Castas que no fue considerada oficialmente concluida sino hasta entrado el siglo XX. 


\section{Al llamado de la Cruz parlante}

En efecto, en julio de 1847, los mayas de Yucatán, sometidos a una explotación económica creciente, y despojados por el nuevo régimen del México ya independiente de los escasos resquicios de autonomía que consagraba la legislación colonial -sin haber obtenido a cambio los derechos plenos de la ciudadanía- se alzaron en armas. Unos pugnaban por pactar con los no indios las condiciones socioeconómicas a fin de remediar abusos y vejaciones; otros, más radicales, plantearon eliminar del territorio peninsular a los «blancos». Tras acciones brutales de uno y otro bando, la rebelión se extendió hasta llegar a controlar las cuatro quintas partes de la Península, sitiando a la misma Mérida.

Desesperado, el gobierno yucateco escribió a Estados Unidos, España e Inglaterra implorando ayuda, y llegó a ofrecer el «dominio y soberanía del país a la nación que tome a su cargo salvarlo». El Gobierno Británico, interesado en continuar explotando el palo de tinte, la caoba y otras maderas preciosas desde las llamadas Honduras Británicas o Walix (hoy Belice), apoyó incluso a los rebeldes, vendiéndoles armamento.

Es imposible reseñar siquiera en este espacio el complejo y dilatado movimiento, que duraría hasta el siglo XX, y supo de diversos intentos de «tratados», con reacciones diversas por parte de grupos nativos asentados en las diferentes partes de la Península, así como de un infame comercio de miles de mayas entre 1848 y 1861 para venderlos como esclavos a Cuba (incluyendo a quienes ni siquiera participaban en la lucha, y hasta a mestizos), y que generó abundante literatura ${ }^{16} \mathrm{e}$ incluso expresiones pictóricas populares (como lo muestran las incluidas en la Figura 4).

Lo que me interesa destacar aquí es el papel que jugó el elemento religioso en el conflicto, en particular desde que en 1850 (cuando numerosos rebeldes optaron por retirarse a las densas selvas orientales), aparecieron estampadas en un árbol tres pequeñas cruces, que se convirtieron en el símbolo de la resistencia maya al Estado yucateco, y dieron incluso nombre a los casi 40.000 sublevados: los cruzo'ob («los de la cruz»), y a su «capital», Chan Santa Cruz.

Desde sus santuarios, la cruz (de hecho, las cruces), que hablaba a través de ciertos mediadores -como lo había hecho en Cancuc la Virgen María (Viqueira 1997)-, se identificaba con los oprimidos, con palabras tales como: «Mi Señor no me puso con los ricos, ni con los generales, ni con los comandantes, ni con los que dicen que tienen montones de dinero, ni con aquellos que muestran orgullo y altanería, si no que me puso con los pobres, con los muy pobres...», arengaba a sus seguidores a continuar la batalla en términos como los siguientes:

«Mis muy queridos compañeros cristianos. Ha llegado el día y la hora para dar a ustedes una señal acerca de las tierras de toda la gente nacida en este mundo, para ser leída a todos los comandantes y ser oída por todos los capitanes, y ser oída por todos los tenientes y ser oída por todos los hijos de la tierra y ser oída por todos mis hijos y descendientes, de modo que ellos, mis hijos, sepan lo que estoy sufriendo tanto bajo la poderosa mano de mi patrón [...]. Yo estoy pensando siempre en ustedes, porque yo los redimí, porque yo derramé mi preciosa sangre por ustedes, cristianos, desde el tiempo en que les creé y les puse en la tierra.

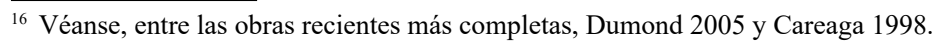



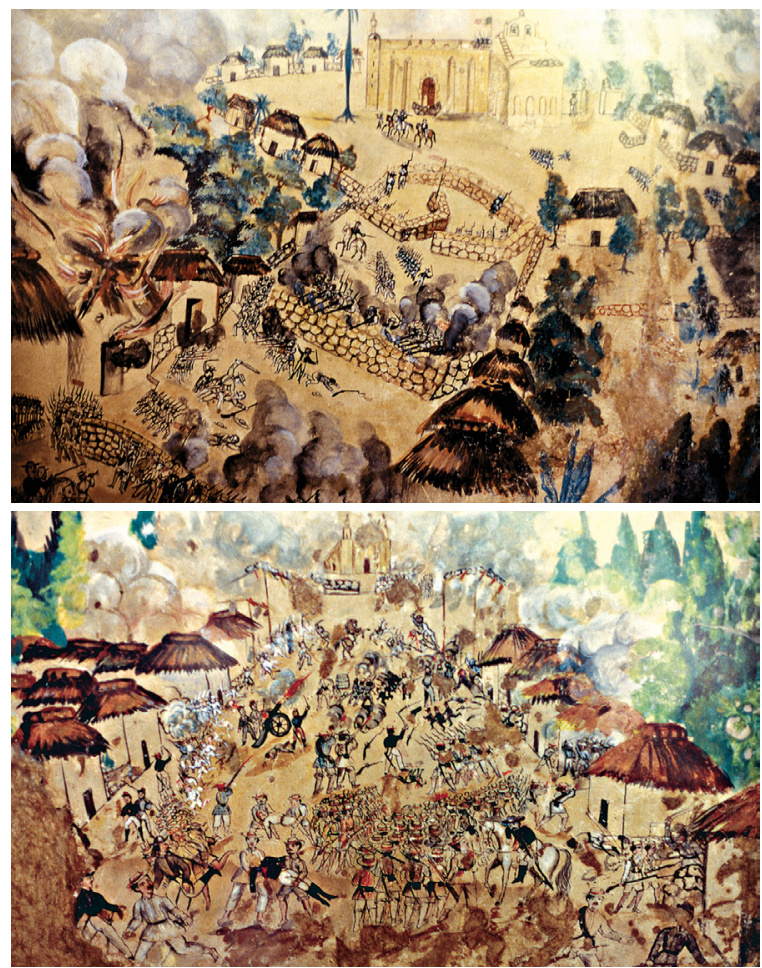

Figura 4. Escenas de la Guerra de Castas. Pinturas anónimas de estilo costumbrista (o «primitivista»).

(C) Museo del Pueblo Maya, Dzibilchaltún, Yucatán.
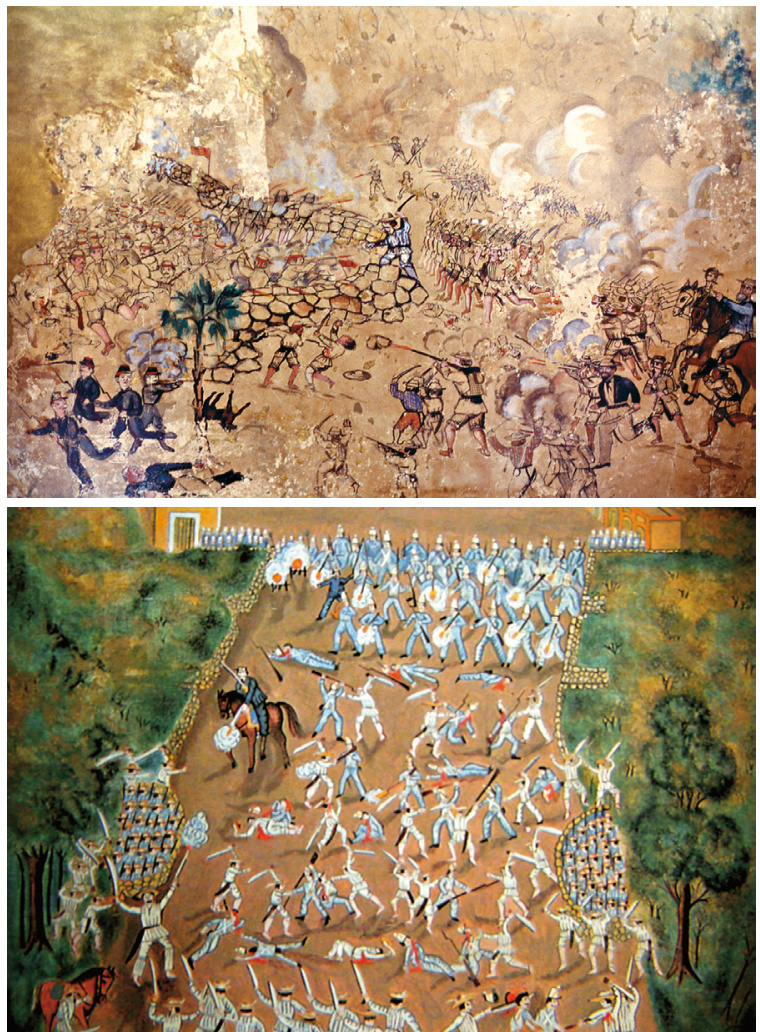
[...] Por lo tanto, mis queridos cristianos, ordeno a ustedes, grandes y pequeños, que sepan que ahora ha llegado el día y el año de que mis indios se levanten una vez más en contra de los blancos, de modo igual a como tuvieron lugar las batallas del pasado $[\ldots]$.

Yo estaré siempre con ustedes, en todo tiempo; estaré siempre como el primero entre ustedes, en la vanguardia, confrontando al enemigo, de modo que nada pueda suceder a ustedes, mis queridos indios.

[...] Porque ha llegado la hora y el año para que en Yucatán se levanten contra los blancos de una vez por todas; de modo que les estoy dejando saber que les daré una señal para que tengan el valor necesario en sus corazones. Porque allí me estaré cayendo todo el tiempo, me estarán hiriendo, clavándome espinas y golpeándome con palos durante mis viajes a Yucatán para defender a ustedes, ¡oh mis amados hombres! $\rangle^{17}$.

Una vez que fracasaron sus intentos por expulsar a criollos y mestizos de la Península, los cruzo'ob optaron por separarse, pretendiendo sobrevivir en el aislamiento al amparo de la Iglesia Maya Cristiana y bajo el cobijo de su cruz parlante, protegida por los cuerpos militares de guardias o «compañías».

Aún hoy, a la par que se mantiene el ya centenario culto a las cruces por toda la Península, en medio del fárrago de millares de turistas de todo el mundo que deambulan por Cancún, el antiguo santuario de Tulum y la Riviera Maya, es posible oír en boca de los ancianos cruzo 'ob que vendrá el tiempo en que vuelva a escucharse la voz de las cruces, incitando a nuevas batallas que permitan la liberación maya. Cientos de kilómetros al sur, en Chiapas, los ancianos tojolabales mantienen la creencia de que existen dos cielos: uno para mestizos y blancos y otro donde los indígenas podrán verse libres de su opresiva presencia. Signos de utopía escatológica donde lo indio podrá al fin disponer de un espacio propio e indisputable.

\section{De resistencias ocultas y soterradas}

Hemos visto, a vuelapluma, algunos ejemplos, entre centenares, que nos ilustran acerca de las maneras en que lo religioso tiñe el mundo maya, haciendo hincapié en periodos en los cuales se conjugaron diversos factores, de naturaleza socioeconómica o política, que alentaron a los mayas a intentar cambios que posibilitaran la supervivencia en mejores condiciones. Todos esos tiempos -fuesen de rechazo, conjunción, subversión, inversión o aislamiento- constituyeron momentos excepcionales para imaginar giros que permitieran recrear tradiciones, para cosechar identidades una y otra vez reinventadas con la siembra de nuevas y antiguas semillas, sobre el campo de lo comunitario y lo étnico, cuidadosamente escardado, regado y abonado.

No se trató de movimientos surgidos ex nihilo, ni de decisiones apresuradas; se anclaron en una cotidianeidad de resistencia al sometimiento, en una lucha, cambiante pero constante, a fin de mantener antiguos referentes mayas a la vez que aprovechar al máximo los nuevos, para beneficio comunal o individual.

La importancia que la cultura maya concede al ámbito de lo sagrado explica que no pocas de las reivindicaciones se gestaran en torno a complejos religiosos, pero, como pudo observarse, pese a mostrar en ocasiones características nativistas o de «revitalización» como asienta Patch en el caso de Canek (2003: 56), tales movi-

\footnotetext{
17 «Sermón de la cruz que habla» (Fragmentos), apud Alfonso Villa Rojas 1978: 461ss.
} 
mientos no pretendieron restaurar los cultos antiguos en forma prístina. De hecho, lo común era amalgamar elementos de ambos sistemas conceptuales, de los cuales se tomaron prestados símbolos y estructuras que conformaban un nuevo universo religioso, no una mera fusión mecánica de ambos. No parece casual que conforme pasaba el tiempo los líderes -algunos educados por el clero o que colaboraban con él- se inclinaran más por la adopción de elementos sin duda cristianos en su origen, pero que ya para entonces formaban parte de las tradiciones comunales y que, al mismo tiempo, a nivel individual, les permitían identificarse en forma más directa con un aparato eclesiástico donde los dominadores eran objeto de un trato privilegiado.

Es asimismo importante recordar que aunque con frecuencia el factor religioso fungió como aglutinante, no era necesariamente el motor mismo de las demandas: es claro que lo que alienta en el fondo de los movimientos es la necesidad de hacer menos tenso el yugo de la explotación, tensión que se percibe con mayor claridad tras o durante catástrofes naturales: sequías, epidemias o plagas. Ciertamente es acerca de esos periodos sobre los que poseemos mayores datos ya que la magnitud de la respuesta indígena generó abundante documentación, pero hay también testimonios que nos hablan de otro tipo de resistencia: la que se gestaba en el ámbito de lo privado, en la secrecía de las viviendas o los adoratorios ocultos en la espesura de selvas y montañas.

Los rituales en montañas y campos eran de hecho pan de cada día como lamentaban obispos, curas y frailes. Andrés de Las Navas, prelado de Guatemala, a quien me referí antes, llegó a escribir hacia 1687 que sus feligreses escapaban a rancherías donde no era posible darles educación cristiana, y que muchos morían sin los santos sacramentos, retornando a ritos con franco tufo heterodoxo, como era de esperar en ésos que calificó de «hijos de la mentira todos, con odio mortal y positivo a sus ministros, como quien tiene su raíz del gentilismo» ${ }^{18}$.

Pero los indios no se consideraban ya ni mentirosos, ni mucho menos «gentiles». En un proceso contra «idólatras» llevado a cabo bajo el periodo de gobierno de ese mismo prelado, el testigo indio Juan Maca puntualizó que, en Comalapa, Guatemala, «cuando van al monte a hacer los sacrificios que lleva referidos, para honestar semejantes maldades, aquel día van a la iglesia y encienden candelas a los santos, haciéndose muy devotos». No se trataba, empero, de un mero afán de «honestar» tales prácticas con un matiz cristiano para despistar a los eclesiásticos; bien se observa en otros documentos que los indios consideraban normal -de hecho, imprescindiblerecurrir a un mismo tiempo a los dos componentes de su mundo ideológico, ya para entonces indivisible.

Claro se advierte esto último en la fórmula empleada por los médicos (ahcunes) que, después de «confesar» al enfermo acudían a la iglesia a depositar una vela en su nombre, para de allí encaminarse a la montaña, no sin antes declarar: «Perdona usté un poco Dios; quizá voy un poco al monte a poner su copal a aquél de antiguo» ${ }^{19}$. En esta perspectiva no extraña que Maca apuntara «que cuando los religiosos les predican en la iglesia y les amonestan que dejen las supersticiones y antigüedades, después de que salen de la iglesia unos con otros dicen ¿que por qué han de dejar lo de sus abuelos y antepasados? ${ }^{20}{ }_{\eta}$

\footnotetext{
${ }_{18}$ AGCA, A1 21, 12 , expediente 23, «Fray Andrés de las Navas al presidente», ff. 23-24v y 138.

${ }^{19}$ Según Antonio Margil de Jesús (ASV, Sac. Cong. Ritii, Proces. Atti vari, Proceso de beatificación, f. 2336v).

${ }^{20}$ AGCA, A1 21, 12 , expediente 23, «Fray Andrés de las Navas al presidente», ff. 21-22v.
} 

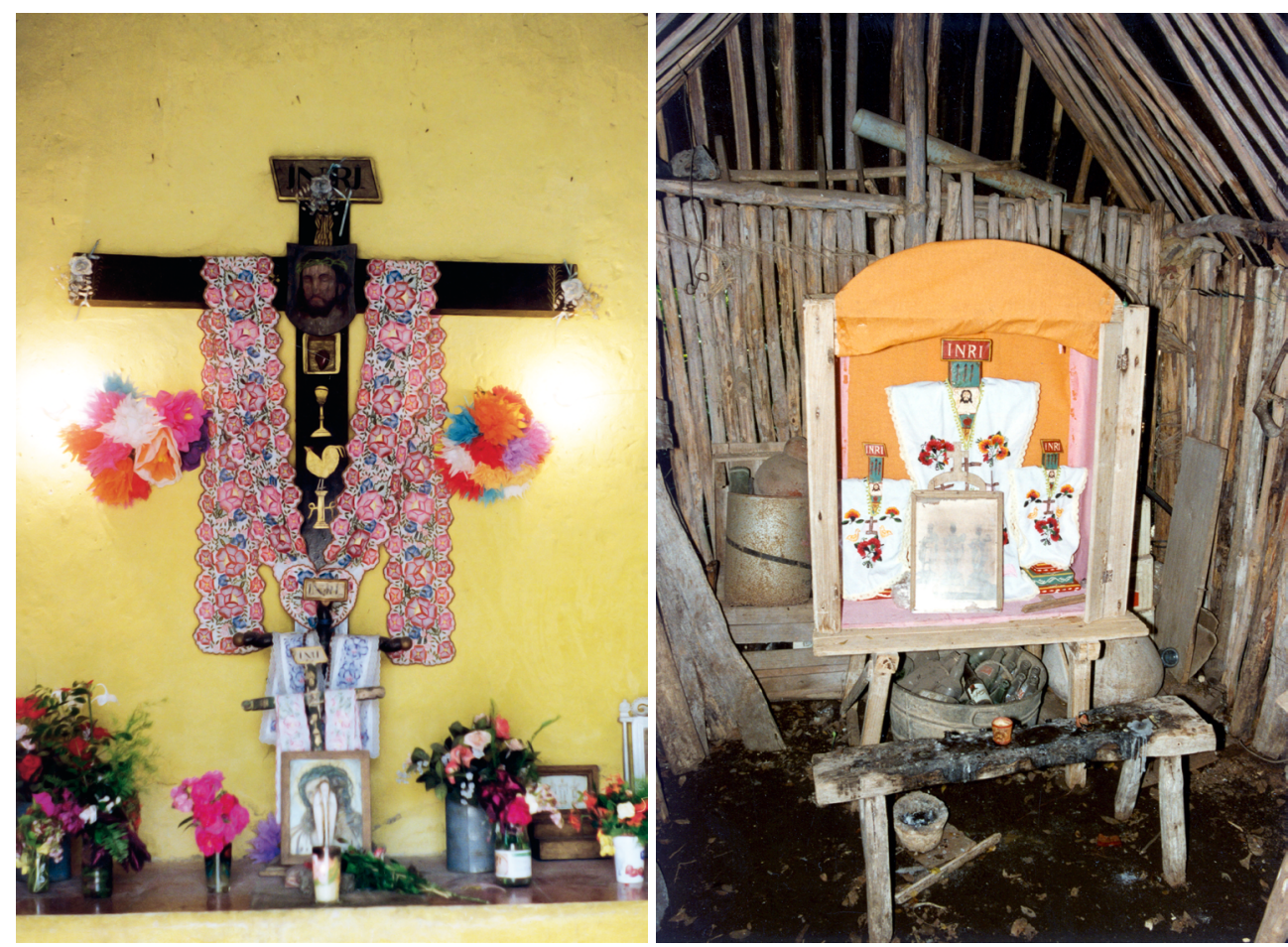

Figura 5. Cruces «vestidas» cuyo culto perdura en ermitas públicas y privadas: a) Ermita barrial de la Santa Cruz, Izamal; b) Ermita familiar en Tixhualactún, Yucatán.

(C) Fotografías de Mario Humberto Ruz.

En efecto, en casas, selvas y montañas, durante la Colonia y el siglo XIX, se continuaron elevando plegarias en la treintena de idiomas mayas, para honrar a santa Eulalia-Tabay, patrona de los cazadores; a san Miguel arcángel, nuevo comandante de los chaques, dispensadores de la lluvia (no en balde sostiene en varias representaciones un rayo o un haz de rayos); a san Antonio Abad, amalgamado con los Dueños de los animales, o a santa Ana, que compartió con Ixchel el cuidado de las parturientas. Las piedras parlantes hablaron en Chamula en tsotsil antes de transmutarse en reverenciadas imágenes de «santos»; en la península yucateca las cruces se fusionaron con los axis mundi, las ceibas (yax) sagradas, al tiempo que se colorearon de verde dando origen a las yax-cruz, se vistieron con huipiles y aprendieron a expresarse en maya (Figura 5).

En el mundo chontal las antiguas invocaciones a los dueños y dueñas de las aguas se ampliaron para incluir a vírgenes y sirenas... Sílabas, fonemas, interjecciones y giros sintácticos de todos y cada uno de esos idiomas se enredaron en las volutas de copal para reverenciar a los patronos de los pueblos o entonar loas a los de las cofradías, al mismo tiempo que retozaban en torno al humo del fogón nocturno, para recordar mitos, conmemorar a los muertos o trasmitir patrones de conducta a los vivos, y permitir así la permanencia de toda una cultura.

Y se apostó por la permanencia no sólo en la esfera de la tradición oral, sino empleando incluso el papel, la tinta y las grafías que aportaron los españoles. Así, textos como el Título de Totonicapan o el Memorial de Sololá (1980) se afanaron por insertar la tradición local en el esquema de la historia de la salvación, único válido para 
los nuevos señores. Combinaron por ejemplo antiguas y nuevas fechas (7 Camey, día de san Francisco; 1 Tziquín, día de Santiago), o revistieron a elementos, héroes y sucesos locales con ropajes bíblicos; Balam Quitzé, ahora denominado «profeta», abre con su bastón de mando las aguas del mar océano durante la migración de los k'ichés, descendientes de Noé, Abraham y Jacob; los idiomas mayas surgen durante la confusión lingüística de Babel...

Los autores de El Título de Totonicapan apuntaron: «[...] nosotros los hebreos vinimos con grandes sufrimientos», «[...] nosotros, las hijas y los hijos de los israelitas, de los cananeos; nosotros los hebreos. Así fue nuestra venida de la salida del sol», «Tenían tres nombres: israelitas, cananeos y hebreos se les llamaba a nuestros abuelos y padres» (1983: 172-174). Y el Título de Pedro Velasco (1989), al esbozar los orígenes de los Tamub se remonta nada menos que hasta el Paraíso terrenal; allí donde se comió «el zapote prohibido».

Pero acaso el compendio más sorprendente de todo ello sea la Historia de los Xpantzay de Tecpan Guatemala, un título original de 1524, en cuyas dos primeras páginas desfilan elementos mayas, nahuas, españoles y hebreos:

«Nosotros los principales, éste es nuestro título, cómo vinieron nuestros abuelos y padres cuando vinieron en la noche, en la oscuridad. Somos los nietos de los abuelos Abraham, Isaac y Jacob, que así se llamaban. Somos, además, los de Israel. Nuestros abuelos y padres quedaron en Canaán... Nosotros también estuvimos en Babilonia, donde hicieron una gran casa, un gran edificio todos los hombres. La cima del edificio creció hasta la mitad del Cielo por obra de todos los hombres. Entonces se hablaba un solo lenguaje por todos los grandes. Luego se separaron en la noche... como eran pecadores, se mudaron las lenguas y se volvieron muy diferentes...

[...] Después se levantaron, llegaron a la orilla del mar y pasaron en siete navíos como los de los españoles. Desembarcaron y descansaron allá las siete tribus de los señores: el Ahpozotzil, Ahpoxahil, Ahpotucuché, Ahpoxohinay, Ahtziquinahay, Xpantzay Noh, Ahau Hulahuh Balam.

Luego se levantaron de la orilla del mar; la mitad caminó por el cielo y la otra mitad andando por la tierra, porque eran grandes brujos y encantadores... llegaron al amanecer a Tub Abah y tocaron el tun» (1957: 121-123).

Otros textos, en particular los chilames de la Península de Yucatán, emplean el referente cronológico del arribo del cristianismo como parteaguas divisorio entre el tiempo de la esclavitud bajo los hispanos y una antigua edad dorada, donde no existían la enfermedad, el hambre ni el tributo. Y no contentos con manipular el pasado, apuestan también a modificar el futuro, pues asimilan a los castellanos con el Anticristo, del que tantos horrores predicaban los frailes (Figura 6), al apuntar «De Anticristo es el rostro del señorío», o «Este es el origen del Anticristo: la avaricia, los avarientos. Si no hubieran venido los 'hombres de Dios' no habría despojos, no habría codicia ni menosprecio de la sangre de otros hombres, ni de las fuerzas de los humildes. De sus propias fuerzas comería cada uno», y dejan clara su confianza en que contra éste, «tigre de los pueblos, gato montés de los pueblos, chupador del pobre indio», bajaría algún día «la justicia de Dios, de un golpe sobre el mundo» (Chilam Balam de Chumayel 1980: 279-280, 227). Y en tanto a la justicia del dios cristiano se le antojaba descender, sus nuevos fieles ideaban estrategias para estar aún vivos cuando se registrara su llegada.

Sobrevivir bajo el opresivo sistema colonial y el celo monoteísta del dios cristiano implicaba cambiar; amalgamar tradiciones propias y ajenas para crear una nueva 


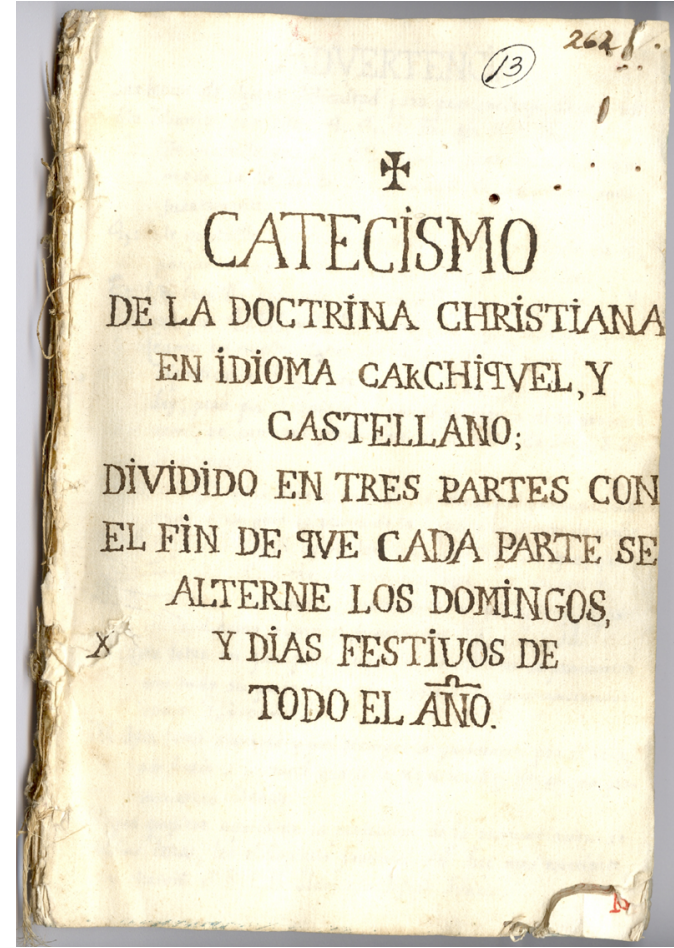

\begin{tabular}{|c|c|c|}
\hline 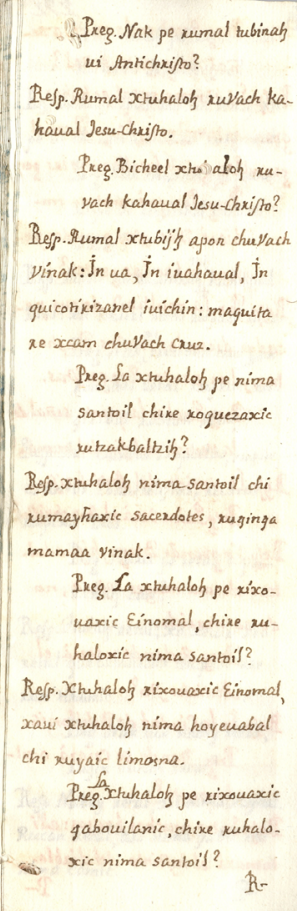 & 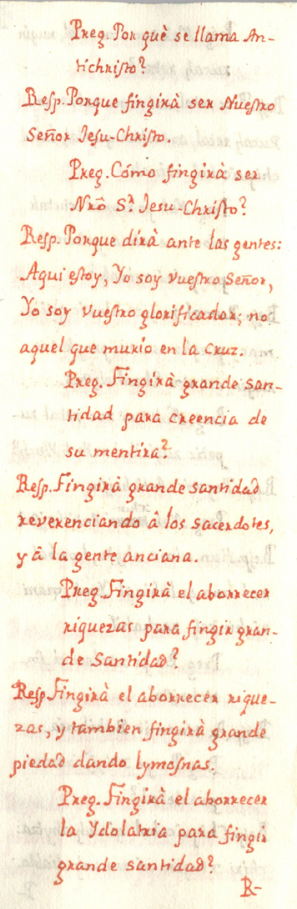 & 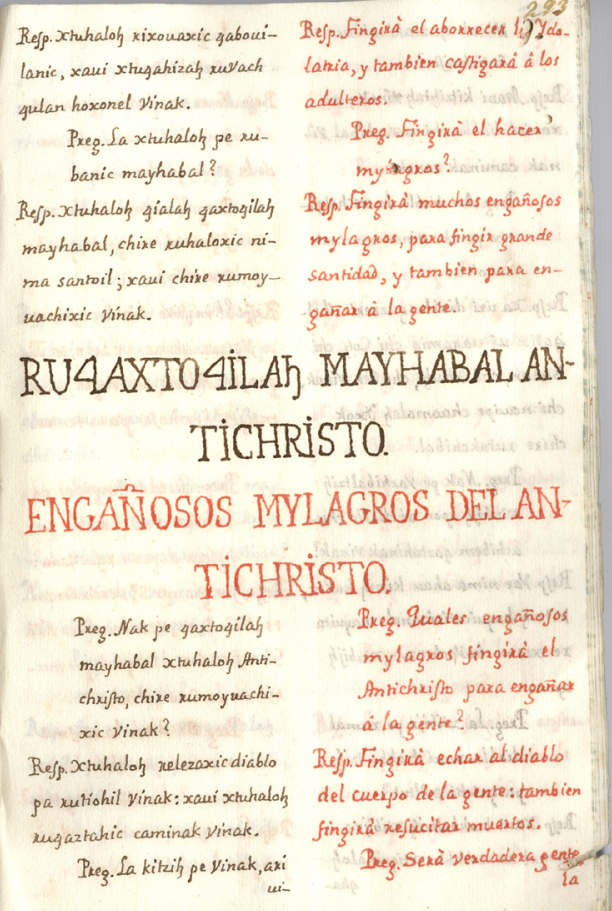 \\
\hline
\end{tabular}

Figura 9. Sección dedicada al Anticristo en el Catecismo de la doctrina christiana en idioma cakchiquel y castellano, Anónimo, s.f. 
cultura que les permitiera seguir siendo mayas pese a no ser nunca más los mayas que antes fueron. La permanencia biológica y cultural de sus descendientes nos muestra que, combinando de manera inteligente, porfiada, y en el momento oportuno, voces, tinta, armas, plegarias y gestos, los pueblos mayas ganaron la apuesta.

\section{Referencias}

\subsection{Referencias documentales}

AGCA (Archivo General de Centro América de Guatemala). A1 21, L 2, expediente 23, «Fray Andrés de las Navas al presidente de la Audiencia, Enrique Enríquez», 21 de febrero de 1687.

AHAG (Archivo Histórico Arquidiocesano de Guatemala). «Expediente que trata de la idolatría en que han incurrido los indios del pueblo de la Concepción, del curato de Jacaltenango, y otros puntos que en él se hallarán». 1797, folios 70-78.

— Procesos eclesiásticos contra indios y mestizos por supuestas actividades de hechicería e idolatría. Segundo legajo: «Expedientes contra hechiceros» (1723 a 1798), expediente VIII: San Miguel Totonicapan, 1797, folios 79-82.

ASV (Archivo Secreto Vaticano). Sagrada Congregación de Ritos (Sac. Cong. Ritii), Proces. Atti vari, Proceso de beatificación de Antonio Margil de Jesús, I, 1744.

\subsection{Referencias bibliográficas}

Bracamonte y Sosa, Pedro. 2004. La encarnación de la profecía. Canek en Cisteil. México: Centro de Investigaciones y Estudios Superiores en Antropología Social.

Bracamonte y Sosa, Pedro y Gabriela Solís Robleda. 1996. Espacios mayas de autonomía. El pacto colonial en Yucatán. Mérida: Universidad Autónoma de Yucatán y Consejo Nacional de Ciencia y Tecnología.

- 2005. Rey Canek. Documentos sobre la sublevación maya de 1761. Mérida: Universidad Nacional Autónoma de México, Centro de Investigaciones y Estudios Superiores en Antropología Social e Instituto de Cultura de Yucatán.

Careaga Viliesid, Lorena. 1998. Hierofanía combatiente. Lucha, simbolismo y religiosidad en la Guerra de Castas. México: Universidad de Quintana Roo y Consejo Nacional de Ciencia y Tecnología.

Chilam Balam de Chumayel. 1980. «Chilam Balam de Chumayel», en Literatura maya, Mercedes de la Garza, ed., prólogo y traducción de Antonio Mediz Bolio. pp. 217-288. Caracas: Biblioteca Ayacucho.

Chuchiak IV, John F. 2004. «It is dieir Drinking that Hinders them': Balché and the Use of Ritual Intoxicants among the Colonial Yucatec Maya, 1550-1780». Estudios de Cultura Maya 24: 137-171.

- 2005. «El retorno de los autos de fe: fray Diego de Landa y la extirpación de las idolatrías en Yucatán, 1573-1579». Península 0: 29-46.

Collins, Anne C. 1989. «La misión mercedaria y la conquista espiritual del occidente de Guatemala», en La sociedad colonial en Guatemala: estudios regionales y locales, Stephen Webre, ed., pp. 1-32. Guatemala: Centro de Investigaciones Regionales de Mesoamérica y PLUMSOCK Mesoamerican Studies. 
Delgado Rojas, Edna P., José A. Silvestre Sánchez, María Elizabeth Silvestre Díaz y Antonio B. Ross Montejo. 2007. Gramática normativa Popti'. Guatemala: Centro Educativo y Cultural Maya Cholsamaj.

Dumond, Don E. 2005. El machete y la cruz. La sublevación de campesinos en Yucatán. México: Unidad Académica de Ciencias Sociales y Humanidades e Instituto de Investigaciones Filológicas, Universidad Nacional Autónoma de México y PLUMSOCK Mesoamerican Studies.

El Título de Totonicapán. 1983. Edición y traducción de Robert Carmack y James Mondloch. Fuentes para el estudio de la Cultura Maya 3. México: Centro de Estudios Mayas, Instituto de Investigaciones Filológicas, Universidad Nacional Autónoma de México.

Farriss, Nancy M. 1984. Maya Society under Colonial Rule. The Collective Enterprise of Survival. Princeton: Princeton University Press.

«Historia de los Xpantzay de Tecpan». 1957. En Crónicas indígenas de Guatemala, pp. 117129, edición, traducción y notas de Adrián Recinos. Guatemala: Editorial Universitaria.

Martínez Peláez, Severo. 1982. La Patria del criollo. Ensayo de interpretación de la realidad colonial guatemalteca. Puebla: Universidad Autónoma de Puebla. 7a. edición.

Memorial de Sololá o Anales de los cakchiqueles y Título de los señores de Totonicapan. 1980. Traducción, introducción y notas de Adrián Recinos. México: Fondo de Cultura Económica.

Moliner, María. 1988. Diccionario de uso del español. 2 vols. Madrid: Gredos.

Patch, Robert W. 2003. «La rebelión de Jacinto Canek en Yucatán: una nueva interpretación». Desacatos 13: 46-59.

Porro, Antonio. 1977. O messianismo maya no periôdo colonial. Tesis doctoral en Antropología Social. Sâo Paulo: Universidad de Sâo Paulo.

Quezada, Sergio. 1993. Pueblos y caciques yucatecos, 1550-1580. México: Centro de Estudios Históricos de El Colegio de México.

Relaciones Histórico-geográficas de la Gobernación de Yucatán. 1983. Mercedes de la Garza, Ana Luisa Izquierdo, $\mathrm{M}^{\mathrm{a}}$ del Carmen León y Tolita Figuera, eds. Fuentes para el estudio de la Cultura Maya 1 y 2. México: Centro de Estudios Mayas, Instituto de Investigaciones Filológicas, Universidad Nacional Autónoma de México.

Ruz, Mario Humberto. 1992. «Los rostros de la resistencia. Los mayas ante el dominio hispano», en Del katún al siglo. Tiempos de colonialismo y resistencia entre los mayas, $\mathrm{M}^{\mathrm{a}}$ del Carmen León, Mario Humberto Ruz y José Alejos, eds., pp. 85-162. México: Consejo Nacional para la Cultura y las Artes.

-1997. Gestos cotidianos. Acercamientos etnológicos a los mayas de la época colonial. Campeche: Instituto de Cultura de Campeche, Universidad Autónoma de Campeche, Universidad Autónoma del Carmen e Instituto Campechano.

- 2007. «Conjuros indígenas, blasfemias mestizas: fragmentos discursivos de la Guatemala colonial». Revista de literaturas populares VI (2): 281-325.

—. 2011. «Las lágrimas de los indios, la justicia de Dios. La resistencia armada maya». Arqueología Mexicana 111: 48-53.

- 2018. «Entraña política, epidermis ritual. Voces y gestos de la nobleza maya en el ámbito colonial». Conferencia presentada en el Coloquio Internacional Temporalités rituelles en Mésoamérique. Approches interdisciplinaires, Groupe de recherche international (GDRI) RITMO, París, 14-16 noviembre.

Ruz, Mario Humberto, Dolores Biosca, Lucy Cervera, Guillermo Luckie, Arturo Moreno, $\mathrm{M}^{\mathrm{a}}$ de la Luz Pérez y Lucía Rendón. 2000. El magnífico señor Alonso López, alcalde de Santa María de la Victoria y aperreador de indios (Tabasco, 1541). México: Centro de 
Estudios Mayas, Instituto de Investigaciones Filológicas, Universidad Nacional Autónoma de México y Plaza Valdés Editores.

Scholes, France V. y Ralph L. Roys. 1968. The Maya-Chontal Indians of Acalan-Tixchel. $2^{\mathrm{a}}$ ed. Norman: University of Oklahoma Press.

«Título de Pedro Velasco». 1989. En El título de Yax y otros documentos quichés, Robert Carmack y James Mondloch, eds. y trads., pp. 139-192. Fuentes para el estudio de la Cultura Maya 8. México: Centro de Estudios Mayas, Instituto de Investigaciones Filológicas, Universidad Nacional Autónoma de México.

Villa Rojas, Alfonso. 1978. Los elegidos de Dios. Etnografía de los mayas de Quintana Roo. México: Instituto Nacional Indigenista.

Viqueira Albán, Juan Pedro. 1997. Indios rebeldes e idólatras. Dos ensayos sobre la rebelión india de Cancuc, Chiapas, acaecida en el año de 1712. México: Centro de Investigaciones y Estudios Superiores en Antropología Social.

Zamora Acosta, Elías. 1986. «Resistencia maya a la colonización: levantamientos indígenas en Guatemala durante el siglo XVI», en Los mayas de los tiempos tardios, Miguel Rivera y Andrés Ciudad, eds., pp. 197-214. Madrid: Sociedad Española de Estudios Mayas. 